J. Akademika Kim. 6(1): 21-27, February 2017

ISSN 2302-6030 (p), 2477-5185 (e)

\title{
EFEK EKSTRAK BUAH SRIKAYA (Annona Squamosa L.) TERHADAP PENURUNAN TEKANAN DARAH PADA MENCIT (Mus musculus).
}

\author{
The Effect of Sugar-Apple Fruit Extract (Annona Squamosa L.) on The \\ Reduction of Blood Pressure in Mice (Mus musculus)
}

\author{
*Fitriani, Daud K. Walanda, Purnama Ningsih \\ Pendidikan Kimia/FKIP - Universitas Tadulako, Palu - Indonesia 94118 \\ Recieved 07 December 2016, Revised 09 January 2017, Accepted 10 February 2017
}

\begin{abstract}
The research aim is to determine the effect of sugar-apple fruit extract on the reduction of blood pressure in mice as the tested animal. The sugar-apple extract was obtained through maceration method with the ratio of sugar-apple fruit powder and water 1:10, after that the heating was done to produce the extract in solid form, then the potassium content was measured by using Spectro Direct. 15 male mice were inducted by adrenaline injection, namely epinephrine. The mice were divided into 5 groups randomly with different treatment. $P_{1}$ was as negative control (-), $P_{2}, P_{3}, P_{4}$ were given the sugar-apple extract with the doses of 50, 100 and $150 \mathrm{mg} / \mathrm{kg}$ bw respectively, while $P_{5}$ was as positive control (+) that was given captopril. The data obtained was analyzed by the statistical analysis, the analysis of variance (ANOVA) and was followed by Duncan's test. The result obtainend that on preclinical testing revealed that the sugar-apple extract was proven to reduce blood pressure of mice and the effective extract was the concentration of $150 \mathrm{mg} / \mathrm{kg}$ with the average blood pressure by $48 \mathrm{mmHg}$.
\end{abstract}

Keywords: apple-sugar, high blood pressure, mice, and maceration method

\section{Pendahuluan}

Bangsa Indonesia telah lama mengenal dan menggunakan tanaman berkhasiat obat sebagai salah satu upaya dalam menanggulangi masalah kesehatan. Pengetahuan tentang tanaman berkhasiat obat berdasarkan pada pengalaman dan keterampilan yang secara turun-temurun telah diwariskan dari satu generasi ke generasi berikutnya. World Health Organization (WHO) tahun 2002 memperkirakan bahwa $80 \%$ penduduk dunia masih mengandalkan dirinya pada pengobatan tradisional termasuk penggunaan obat yang berasal dari tanaman (Gusmira, 2012).

Menurut Tarigan (1990) penggunaan tuanaman herbal juga semakin banyak diminati oleh masyarakat karena telah terbukti bahwa obat yang berasal dari tanaman lebih menyehatkan dan tanpa menimbulkan adanya efek samping dibanding dengan obat-obatan yang berasal dari bahan kimia. Pemanfaatan tanaman yang dijadikan sebagai bahan pengobatan berbagai penyakit telah dikenal dan

\section{*Correspondence:}

Fitriani

Program Studi Pendidikan Kimia, Fakultas Keguruan dan Ilmu Pendidikan, Universitas Tadulako

email: fitrichemistry11@gmail.com

Published by Universitas Tadulako 2017

dilakukan sejak zaman dahulu kala (Mustikasari \& Ariyani, 2008). Pemulihan kesehatan dengan menggunakan tanaman obat tradisional tetap berlanjut hingga saat ini, bahkan cenderung meningkat (Kristian, 2013).

Pemanfaatan keanekaragaman hayati dalam bentuk penggunaan obat-obatan tradisional merupakan alternatif yang dinilai lebih ekonomis, karena penggunaan obat-obatan tradisional yang diolah secara moderen sulit dijangkau harganya oleh masyarakat yang kurang mampu (Sangi, dkk., 2012).

Penggunaan obat tradisional yang merupakan salah satu program pelayanan kesehatan dasar dan juga merupakan salah satu alternatif untuk dapat memenuhi kebutuhan dasar pengobatan, khususnya tanaman yang berkhasiat obat dalam rangka pelayanan kesehatan masyrakat (Inawati, dkk., 2006).

Provinsi Sulawesi Tengah adalah daerah khatulistiwa yang beriklim tropis dan secara topografi merupakan daerah pegunungan, berbukit-bukit dengan datarannya rendah. Sulawesi Tengah sebagai daerah tropis banyak ditumbuhi berbagai macam tanaman yang dapat dijadikan sebagai tanaman herbal (Sudarni, 2000). Salah satunya yaitu tanaman srikaya yang ternyata tidak hanya dikenal dengan 
buahnya yang manis dan lezat, akan tetapi tanaman srikaya ini ternyata juga memiliki banyak kegunaan. Mulai dari buah, daun, kulit pohon, sampai biji bisa digunakan untuk berbagai keperluan. Buah ini selain mudah ditanam juga memiliki kandungan vitamin dan mineral yang memberikan berbagai manfaat kesehatan yang salah satu mineralnya yaitu unsur kalium yang dikenal bisa mengendalikan tingkat tekanan darah dengan mengontrol efek sodium dalam tubuh, sehingga buah ini dapat dijadikan sebagai obat antihipertensi (Soedarso, 2012).

Hipertensi adalah faktor risiko utama penyakit-penyakit kardiovaskular yang merupakan penyebab kematian tertinggi di Indonesia. Menurut Depkes RI (2009), stroke dan penyakit jantung meliputi lebih dari sepertiga penyebab kematian, dimana stroke menjadi penyebab kematian terbanyak 15,4\%, kedua hipertensi $6,8 \%$, dan jantung $4,6 \%$ (Departemen Kesehatan RI, 2009).

Tujuan dilakukan penelitian ini adalah yaitu untuk menguji ekstrak buah srikaya dalam menurunkan tekanan darah dan kosentrasi ekstrak buah srikaya yang efektif dalam menurunkan tekanan darah pada mencit. Pengujian efek ekstrak buah srikaya dalam menurunkan tekanan darah pada mencit ini dapat menambah wawasan keilmuan dibidang keilmuan kimia, khususnya tentang pemanfaatan senyawa aktif dari ekstrak buah srikaya (Annona Squamosa L.) sebagai obat untuk menurunkan tekanan darah.

\section{Metode \\ Alat dan Bahan}

Alat dan bahan yang digunakan adalah Neraca digital, sonde, spoit, blood pressure analyzer (alat pengukur tekanan darah merek omron), gelas kimia, kandang hewan uji, timbangan hewan, batang pengaduk, talenan, aluminium foil, magnetik stirer, kain flannel, oven MMM Medcenter, hotplate, spektrodirect RS232 serial No: 1257060900344 , coronggelas, tablet potassium (Lovibond), buah srikaya, hewan uji (mencit), aquades, makanan standar untuk mencit, obat epinephrine (Phapros) dan obat captopril (Hexpharm).

\section{Cara Kerja}

Pembuatan ekstrak buah srikaya

Buah srikaya dikeringkan dengan menggunakan oven dengan suhu $65^{\circ} \mathrm{C}$. Setelah itu diambil 50 gram buah srikaya dan diblender, kemudian dimaserasi dengan menggunakan aquades sebanyak $500 \mathrm{~mL}$ selama 48 jam.
Kemudian disaring menggunakan kertas saring. Penyaringan dilakukan dua kali. Filtrate dipekatkan dengan menggunakan hot plate pada suhu $100^{\circ} \mathrm{C}$ sehingga diperoleh ekstrak yang berbentuk padatan (Samawiyah, 2014).

Uji kuantitatifkadar kalium ekstrak buah srikaya 2 gram ekstrak buah srikaya dilarutkan ke dalam aquades yang kemudian dipindahkan ke dalam labu takar 1 L. Setelah itu diencerkan dengan aquades hingga tepat $1 \mathrm{~L}$ dan larutan induk kalium $(\mathrm{K})$ siap digunakan dan diukur kadar kaliumnya dengan menggunakan alat SpektroDirect (Samawiyah, 2014).

\section{Pemilihan dan penyiapan hewan uji}

Hewan uji yang digunakan adalah mencit yang bercirikan berbadan sehat, berumur 2-3 bulan dengan bobot badan yang bervariasi antara 20 gram sampai 30 gram dan mencit yang digunakan sebanyak 15 ekor dan dibagi dalam 5 kelompok perlakuan, dengan jumlah tiap kelompok sebanyak 3 ekor.

\section{Perlakuan terhadap hewan uji}

Sebelum diberikan perlakuan hewan uji tersebut diadaptasi selama satu minggu dan diberikan konsumsi makanan standar dan air minum ad libitum. Kemudian diukur tekanan darah awal. Setelah itu, semua hewan dikelompokan dan diinduksikan secara oral dengan menggunakan epinephrine sebanyak $0,5 \mathrm{~mL}$ setiap hari selama satu minggu

Adapun perlakuan yang dilakukan terhadap hewan uji mencit yang dibagi menjadi 5 kelompok adalah sebagai berikut :

P1 : pakan standar + obat epinephrine + aquades; $\mathrm{P} 2$ : pakan standar + obat epinephrine + ekstrak buah srikaya dosis $50 \mathrm{mg} / \mathrm{kg} \mathrm{BB}$ mencit; P3 : pakan standar + obat epinephrine + ekstrak buah srikaya dosis $100 \mathrm{mg} / \mathrm{kg} \mathrm{BB}$ mencit; P4 : pakan standar + obat epinephrine + ekstrak buah srikaya dosis $150 \mathrm{mg} / \mathrm{kg}$ BB mencit dan P5 : pakan standar + obat epinephrine + obat captopril

Pemberian ekstrak buah srikaya ini dilakukan setiap hari secara oral selama 2 minggu. Pemberian ekstrak buah srikaya ini dilakukan 3 kali sehari pada jam 08.00, 14.00, dan 20.00. setelah 2 minggu dilakukan pengukuran tekanan darah mencit pada masing-masing kelompok (Samawiyah, 2014).

\section{Pemeriksaan Tekanan Darah}

Pengukuran tekanan darah pada mencit menggunakan alat blood pressure analyzer dengan metode tail cuff, dimana metode 
ini sangat memungkinkan peneliti untuk mengetahui tekanan darah sistolik dan diastolik. Adapun prinsip kerja dari pengukuran darah tersebut adalah Cuff digelembungkan sampai mencapai tekanan darah di atas tekanan darah sistolik, sehingga nadi menghilang kemudian tekanan Cuff dikurangi perlahan-lahan. Pada saat tekanan darah mencapai dibawah tekanan sistolik nadi akan muncul kembali dan cara pengukuran ini sesuai dengan cara pengukuran tekanan darah menggunakan sphigmomanometer pada manusia.

\section{Pengumpulan dan Analisis Data}

Pengumpulan data dilakukan dengan mengukur tekanan darah awal hewan uji, kemudian mengelompokannya dalam 5 kelompok dengan tekanan darah ratarata setiap kelompok seimbang. Kemudian dilakukan peningkatan tekanan darah buatan dengan memberikan obat epinephrine lalu diberikan ekstrak dari sampel dan diukur tekanan darahnya setelah 2 minggu. Selisih tekanan darah awal dengan tekanan darah akhir merupakan hasil dari efek pemberian ekstrak buah srikaya.

\section{Hasil dan Pembahasan \\ UjiKuantitatif Kadar Kalium}

Berdasarkan hasil uji kandungan kalium pada ekstrak buah srikaya maka diperoleh kandungan kalium sebesar 93,6 mg/100 gram. Kandungan kalium pada buah srikaya ini lebih banyak dibandingkan dengan buah pisang, yaitu pada buah srikaya terdapat 578 mg kalium/100 gram daging buah sedangkan buah pisang terdapat $85 \mathrm{mg} / 100$ gram daging buah (Soedarso, 2012). Beberapa penelitian yang menunjukkan peran kalium terhadap hipertensi yaitu berdasarkan penelitian yang dilakukan oleh Solanki (2011)yang menyatakan beberapa mekanisme bagaimana kalium dapat menurunkan tekanan darah sebagai berikut: kalium dapat menurunkan tekanan darah dengan menimbulkan efek vasodilatasi sehingga menyebabkan penurunan retensi perifer total meningkatkan output jantung. Konsumsi kalium yang banyak akan meningkatkan konsentrasinya di dalam cairan intraseluler sehingga cenderung menarik cairan dari bagian ekstraseluler dan menurunkan tekanan darah (Amran, 2010).

Pengujian efek penurunan tekanan darah dengan menggunakan uji statistik dapat dilihat pada Tabel 1 dimana tekanan darah awal dibandingkan setelah induksi dan setelah diberikan perlakuan dan penurunan tekanan darah adalah seperti terlihat pada Tabel 1.

Tabel 1 Rerata penurunan tekanan darah awal setelah induksi kemudian diberikan perlakuan

dan penurunan tekanan darah total mencit.

\begin{tabular}{ccccc}
\hline Perlakuan & $\begin{array}{c}\text { Tekanan } \\
\text { Darah Awal } \\
(\mathrm{mmHg})\end{array}$ & $\begin{array}{c}\text { Tekanan Darah } \\
\text { Setelah } \\
\text { Induksi } \\
(\text { mmHg) }\end{array}$ & $\begin{array}{c}\text { Tekanan Darah } \\
\text { setelah } \\
\text { Perlakuan } \\
\text { selama 2 } \\
\text { minggu (mmHg) }\end{array}$ & $\begin{array}{c}\text { Penurunan } \\
\text { Tekanan } \\
\text { Darah Total } \\
(\mathrm{mmHg})\end{array}$ \\
\hline P1 (-) & 120 & 163 & 166 & -2 \\
P2 & 120 & 174 & 152 & 22 \\
P3 & 118 & 166 & 140 & 26 \\
P4 & 117 & 170 & 121 & 48 \\
P5 (+) & 118 & 172 & 121 & 51 \\
\hline
\end{tabular}

Keterangan:P1 : pakan standar + obat epinephrine + aquades ; P2 : pakain standar + obat epinephrine + ekstrak buah srikaya dosis $50 \mathrm{mg} / \mathrm{kg}$ bb mencit; P3 : pakan standar + obat epinephrine + ekstrak buah srikaya dosis 100 $\mathrm{mg} / \mathrm{kg}$ bb mencit ; P4 : pakan standar + obat epinephrine + ekstrak buah srikaya dosis 150 $\mathrm{mg} / \mathrm{kg}$ bb mencit ; P5 : pakan standar + obat epinephrine + Captopril.

\section{Pengaruh Dosis Ekstrak Buah Srikaya Terhadap Penurunan Tekanan Darah Tinggi}

Penelitian ini menggunkan hewan uji mencit, umur 2-3 bulan dengan berat ratarata 20 sampai 30 gram. Mencit tersebut terlebih dahulu diadaptasi selama satu minggu tujuannya yaitu untuk menyesuaikan dengan lingkungannya agar tidak mempengaruhi proses selama penelitian. Setelah itu mencit tersebut diukur tekanan darah awal dengan menggunakan alat blood pressure analzer. Selajutnya masing-masing kelompok diinduksi dengan injeksi adrenalin yaitu epinephrine. Hewan uji dibuat hipertensi dalam keadaan teranastesi, tujuannya untuk memberikan rangsangan pada system kardiosvaskuler dengan pemberian suntikan epinephrine $0.2 \mathrm{~mL}$ (Djatmiko, dkk., 2001). Akibat penyuntikan epinephrine maka tekanan darah hewan uji meningkat menjadi $174 \mathrm{mmHg}$ (tekanan darah normal $120 \mathrm{mmHg}$ ). Rangsangan pada sistem kardiovaskuler dengan epineprhine ini dilakukan sebelum penyuntikan larutan uji.

Pengukuran terhadap tekanan darah pada mencit yang diinduksi dengan epinephrine secara oral selama satu minggu mengalami kenaikan tekanan darah tinggi. Untuk mengetahui seberapa besar penurunan tekanan darah, maka dilakukan perhitungan selisi antara tekanan darah awal, pemberian induksi epinephrine dan setelah pemberian perlakuan 
kemudian dihitung reratanya (Tabel 1), ilustrasinya dapat dilihat pada Gambar 1.

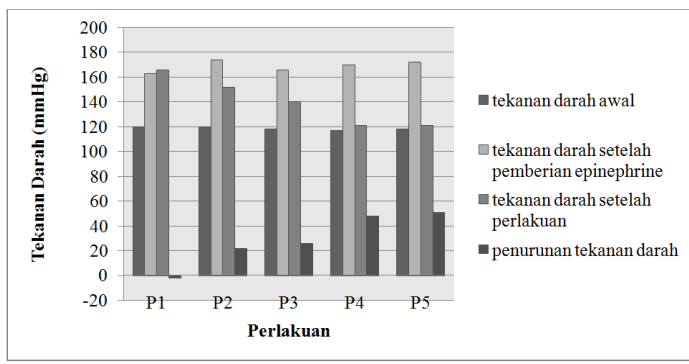

Gambar 1. Grafik rata-rata tekanan darah awal, setelah pemberian epineprin dan penurunan tekanan darah pada mencit

Rata-rata penurunan tekanan darah mencit berbeda antara kelima perlakuan dimana pada perlakuan P1 sebagai kontrol negatif menunjukkan penurunan tekanan darah tidak begitu signifikan. Kemudian pada perlakuan P2, P3 dan P4 dengan dosis yang berbedabeda yaitu $50 \mathrm{mg} / \mathrm{kg}$ bb mencit, $100 \mathrm{mg} / \mathrm{kg}$ bb mencit, $150 \mathrm{mg} / \mathrm{kg}$ bb mencit hasil yang terlihat sangat berbeda dimana hasil dari penurunan tekanan darah yang efektif yaitu pada perlakuan $\mathrm{P} 4$ dengan dosis $150 \mathrm{mg} / \mathrm{kg}$ bb mencit dengan rata-rata penurunannya yaitu 48 $\mathrm{mmHg}, \mathrm{P} 2$ dengan dosis $50 \mathrm{mg} / \mathrm{kg}$ bb mencit hanya mampu menurunkan sekitar $22 \mathrm{mmHg}$, dan P3 dengan dosis $100 \mathrm{mg} / \mathrm{kg}$ bb mencit hanya mampu menurunkan sekitar $26 \mathrm{mmHg}$ sedangkan untuk perlakuan P5 yang dijadkan sebagai kontrol positif atau dijadikan sebagai pebanding juga mengalami penurunan secara signifikan karena obat captopril merupakan salah satu obat dalam golongan ACE inhibitor yaitu menghambat pembentukkan angiotensin I menjadi angiotensin II oleh angiotensin corverting enzyme (Carrasco, dkk., 2010).

Hasil pada Gambar1 menunjukkan bahwa rerata tekanan darah normal yaitu berkisar antara $117-120 \mathrm{mmHg}$ dan setelah induksi berkisar antara 163-174 mmHg. Hal ini sesuai dengan yang dinyatakan oleh Septian \& Widianingsih (2014) bahwa tekanan darah normal berkisar antara $100-140 \mathrm{mmHg} /$ 60-90 $\mathrm{mmHg}$ dan dikatakan tekanan darah tinggi bila nilai tekanannya diatas $140 \mathrm{mmHg}$ / $90 \mathrm{mmHg}$ secara berkelanjutan. Hasil tekanan darah awal ini menujukkan tidak ada perbedaan yag signifikan antar kelompok, hasil uji homogenitas tekanan darah awal mencit antar kelompok perlakuan ( $\mathrm{p}>0.05$ atau nilai signifikan $0.313>0.05$ ), sehingga semua kelompok perlakuan layak untuk perlakuan selanjutnya.
Hasil homogenitas tekanan darah mencit setelah diinduksi dengan epinephrine, menunjukkan tidak ada perbedaan yang signifikan antar kelompok perlakuan $(\mathrm{p}>0.05$ atau nilai signifikan $0.063>0.05$ ). Demikian, semua kelompok perlakuan layak dibandingkan karena tidak ada perbedaan yang signifikan.

Hasil rerata tekanan darah akhir berkisar antara 120-166 mmHg. Hasil tekanan darah akhir menunjukkan tidak ada perbedaan yang signifikan antar kelompok, hasil uji tekanan darah akhir antar kelompok perlakuan ( $p$ $>0.05$ atau nilai signifikan $0.102>0.05$ ). Demikian, semua kelompok perlakuan layak dibandingkan karena tidak ada perbedaan yang signifikan atau kelompok perlakuan homogen.

Hasil uji antihipertensi pada ektrak buah srikaya, dimana hasil yang menujukkan bahwa ektrak buah srikaya dengan dosis $150 \mathrm{mg} / \mathrm{kg}$ bb yang efektif karena mampu menurunkan tekanan darah rata-rata yaitu $48 \mathrm{mmHg}$, hal ini disebabkan karena pada dosis tersebut lebih banyak mengandung kalium dibandingkan dengan dosis 50 dan $100 \mathrm{mg} / \mathrm{kg}$ bb.

Kalium merupakan elektrolit intraseluler yang utama. 98\% kalium di tubuh berada di dalam sel dan $2 \%$ sisanya berada di luar sel. Kalium mempengaruhi aktivitas baik otot skelet maupun otot jantung. Sebagai contoh, perubahan dalam konsentrasinya mengubah iritabilitas dan ritme miokardia. Kalium secara konstan bergerak ke dalam dan keluar sel tergantung pada kebutuhan tubuh (Smeltzer, dkk., 2001).

Kalium berperan dalam pemeliharaan keseimbangan cairan dan elektrolit serta keseimbangan asam basa. Bersama kalsium, kalium berperan dalam transmisi saraf dan relaksasi otot di dalam sel, di dalam sel kalsium berfungsi sebagai katalisator dalam banyak reaksi biologis, terutama dalam metabolisme energi dan sintesis glikogen dan protein. Kalium membantu menyeimbangkan tekanan darah dan diperlukan reaksi enzim, serta metabolisme karbohidrat dan protein. Kalium yang membantu pengeluaran racun melalui ginjal, bekerja sama dengan posforuss untuk mengirim oksigen ke otak, akibat kekurangan kalium dapat menyebabkan henti jantung, hipertensi, menurunnya fungsi hormonadrenal dan otot kehilangan fungsi kontraksinya (Genilda, dkk., 2013).

Asupan kalium pada seseorang dapat mempengaruhi tekanan darah. Peningkatan asupan kalium dapat menurunkan tekanan darah, penurunan tekanan darah ini dapat dikarenakan adanya penurunan resistensi 
vaskular akibat dilatasi pembuluh darah serta adanya peningkatan kehilangan air dan natrium dari tubuh hasil aktifitas pompa natrium dan kalium. Natrium dan kalium mempunyai peran penting dalam mengatur keseimbangan cairan dalam tubuh. Fungsi mineral natrium $(\mathrm{Na})$ merupakan kation utama yang terdapat pada cairan ekstraselular, sedangkan kalium (K) merupakan kation utama pada cairan intraselular. Jika kedua mineral tersebut tidak berimbang, air akan mengalir ke dalam atau ke luar sel untuk menjaga konsentrasi $\mathrm{Na}$ dan $\mathrm{K}$ agar tetap berimbang. Asupan kalium idealnya adalah 4.7 gram/hari dan dapat diperoleh dari buah dan sayur yang mengandung kalium tinggi (Genilda, dkk., 2013).

Hasil pada keadaan sesudah perlakuan data dianalisis menggunakan statistik menggunakan analisis varians (ANOVA) untuk melihat ada atau tidak perbedaan tekanan darah tiap kelompok dan diperoleh rata-rata tekanan darah yang berbeda nyata $(\alpha=0.05)$ antar kelompok perlakuan terlihat pada Tabel 2.

Tabel 2. Hasil Uji Anova untuk penurunan tekanan darah

\begin{tabular}{cccccc}
\hline & $\begin{array}{c}\text { Sum of } \\
\text { Squares }\end{array}$ & Df & Mean Square & F & Sig. \\
\hline $\begin{array}{c}\text { Between } \\
\text { Groups }\end{array}$ & 5781.733 & 4 & 1445.433 & 22.871 & .000 \\
Within Groups & 632.000 & 10 & 63.200 & & \\
Total & 6413.733 & 14 & & & \\
\hline
\end{tabular}

Tabel 2 menunjukkan hasil bahwa antar perlakuan mempunyai nilai signifikan 0.000 $<\alpha=0.050$ atau nilai F hitung 22.871 lebih besar dibandingkan nilai $\mathrm{F}$ tabel 3,48. Hal ini menandakan bahwa terdapat penurunan tekanan darah yang cukup bermakna dari ke empat kelompok perlakuan yaitu P2, P3, P4, dan P5. Jadi keempat kelompok tersebut memiliki efektivitas yang cukup berbeda dalam menurunkan tekanan darah total mencit kemudian dilakukan uji lanjutan yaitu uji Duncan dimana uji ini bertujuan untuk mengetahui perbedaan bermakna dari kelima kelompok percobaan tersebut sehingga dari hasil perhitungannya dapat diketahui dosis yang efektif dalam menurunkan tekanan darah total mencit. Adapun hasil dari perhitunganya terlihat pada Tabel 3.

Hasil perhitungan statistik dari uji Duncan untuk penurunan tekanan darah total menunjukkan bahwa pada kontrol negatif (P1) yaitu perlakuan tanpa ekstrak buah srikaya dan obat captopril menunjukan adanya perbedaan
Tabel 3 Hasil uji Duncan Terhadap

Penurunan Tekanan Darah Total Mencit

\begin{tabular}{ccccc}
\hline & \multicolumn{4}{c}{ Subset for alpha $=0.05$} \\
\cline { 3 - 5 } Perlakuan & $\mathrm{N}$ & 1 & 2 & 3 \\
\hline P1 & 3 & -2.3333 & & \\
P2 & 3 & & 22.0000 & \\
P3 & 3 & & 26.0000 & \\
P4 & 3 & & & 48.3333 \\
P5 & 3 & & & 51.6667 \\
Sig. & & 1.000 & .552 & .619 \\
\hline
\end{tabular}

nyata jika dibandingkan dengan keempat perlakuan lainnya yaitu dimana pada perlakuan P2 dan P3 tidak berbeda nyata atau dengan kata lain tidak signifikan sedangkan untuk perlakuan P4 dan P5 menunjukkan tidak berbeda nyata dan signifikan dari ketiga perlakuan lainnya, dimana P5 ini bertindak sebagai kontrol positif atau pembanding. Sehingga dari hasil tersebut dapat diketahui bahwa dosis yang efektif dalam menurunkan tekanan darah yaitu dosis 150 $\mathrm{mg} / \mathrm{kg}$ bb dibandingkan dengan dosis 50 dan $100 \mathrm{mg} / \mathrm{kg}$ bb. Hal ini disebabkan karena kandungan kalium kalium yang ada pada dosis $150 \mathrm{mg} / \mathrm{kg}$ bb lebih banyak sehingga mempunyai efek antihipertensinya lebih besar dibandingkan dengan ekstrak buah srikaya dengan dosis 50 dan $100 \mathrm{mg} / \mathrm{kg}$ bb.

Pengaruh kandungan buah srikaya terhadap tekanan darah terlihat jelas dalam peranankalium dalam menjaga kestabilan elektrolit tubuh melalui pompa kalium-natrium. Kurangnya kadar kalium dalam darah akan mengganggu rasio kalium-natrium sehingga kadar natrium akan meningkat. Hal ini dapat menyebabkan pengendapan kalsium pada persendian dan tulang belakang yang menigkatkan kadar air tubuh. Sehingga meningkatkan beban kerja jantung dan penggumpalan natrium dalam pembuluh darah. Akibatnya dinding pembuluh darah dapat terkikis dan terkelupas yang pada akhirnya menyumbat aliran darah sehingga meningkatkan resiko hipertensi sehingga dengan mengkonsumsi buah srikaya hal ini kemungkinan dapat dihindari sedangkan magnesium berperan dalam mengaktifkan pompa natrium-kalium, yang memompa natrium keluar dan kalium masuk ke dalam sel (Julianti, dkk., 2005).

Mekanisme bagaimana kalium dapat menurunkan tekanan darah adalah sebagai 
berikut: pertama, kalium dapat menurunkan tekanan darah dengan vasodilatasi sehingga menyebabkan penurunan retensi perifer total dan meningkatkan output jantung. Kedua, kalium dapat menurunkan tekanan darah dengan berkhasiat sebagai diuretika. Ketiga, kalium dapat mengubah aktifitas sistem reniangiotensin. Keempat, kalium dapat mengatur saraf perifer dan sentral yang mempengaruhi tekanan darah. Berbeda dengan natrium, kalium (potassium) merupakan ion utama di dalam intraseluler. Cara kerja kalium adalah kebalikan dari natrium. Konsumsi kalium yang banyak akan meningkatkan konsentrasi dalam cairan intraseluler sehingga cenderung menarik cairan dalam bagian ektraseluler dan menurunkan tekanan darah (Amran, 2010).

Penurunan tekanan darah terjadi karena efek diuretika dari produk tersebut. Ada tiga faktor yang dapat mempengaruhi tekanan darah, antara lain kapasitas kerja jantung, elastisitas pembuluh darah dan faktor darah itu sendiri, misal viskositas dan volume darah. Setelah pemberian ekstrak ternyata telah terjadi penurunan tekanan darah, hal ini menandakan bahwa pemberian ekstrak tersebut mempunyai kemampuan untuk mempengaruhi salah satu dari ketiga faktor tersebut. Penurunan tekanan darah sebanyak 5-6 $\mathrm{mmHg}$ dapat mengurangi resiko terkena serangan stroke sampai $40 \%$, penyakit jantung koroner $15-20 \%$ dan mengurangi kegagalan jantung, penyakit jantung (Djatmiko, dkk., 2001).

Efek samping dari hipertensi adalah meningkatkan serangan jantung, kegagalan jantung, stroke dan kerusakan ginjal. Hasil penelitian terhadap (Bovet, dkk., 2002). volunter menunjukan bahwa penurunan tekanan darah $7 \mathrm{mmHg}$ terjadi setelah meminum obat antihipertensi $0-3$ hari perminggu, dengan tekanan darah awal $158 \mathrm{mmHg}$. Bila mengkonsumsi obat 6-7 hari perminggu maka tekanan darah akan turun sampai $16 \mathrm{mmHg}$. Dari penggunaan obat antihipertensi terhadap pasien dapat mengurangi resiko kena stroke sampai $18 \%$, penyakit jantung koroner $16 \%$ dan kematian pecah pembuluh darah 21\%. Penurunan tekanan darah rata-rata 5-6 $\mathrm{mmHg}$ untuk diastolik dan 10-12 mmHg untuk sistolik (Lindhlom, 2003).

\section{Kesimpulan}

Ekstrak buah srikaya (Annona Squamosa L.) dapat menurunkan tekanan darah pada mencit. Dosis yang efektif yaitu $150 \mathrm{mg} / \mathrm{kg}$ bb dengan rata-rata penurunan tekanan darah sebesar 48 $\mathrm{mmHg}$ dibandingkan dengan dosis $100 \mathrm{mg} / \mathrm{kg}$ bb yang hanya mampu menurunkan tekanan darah rata-rata $26 \mathrm{mmHg}$ sedangkan dosis 50 $\mathrm{mg} / \mathrm{kg}$ bb hanya mampu menurunkan tekanan darah rata-rata sebesar $22 \mathrm{mmHg}$.

\section{Ucapan Terima Kasih}

Penulis mengucapkan terima kasih kepada laboran Laboratorium Kimia FKIP Universitas Tadulako dan semua pihak yang telah banyak membantu penulis dalam menyelesaikan penelitian ini.

\section{Referensi}

Amran, Y. (2010). Pengaruh tambahan asupan kalium dari diet terhadap penurunan hipertensi sistolik dan diastolik tingkat sedang pada lanjut usia. Artikel Penelitian Universitas Islam Negeri Syarif Hasanudin. 28(2), 91.

Bovet, P., M. , Burnier, G., Madeleine, B., Waeber., \& Pascaud., F. (2002). Monitoring one year compliance to antihypertension medication in the seychelles. Bull World Health Organization Genebra. 80(1), 108.

Carrasco, J. L. M., Zambrano, S., Blanca, A. C., Mate, A., \& Vazques, C. M. (2010). Captopril reduces cardiac inflammatory markers in spontaneously hypertensive rats by inactivation Of NF-kB. Journal of Inflammation. 7(2), 21.

Departemen Kesehatan RI (2009). Rumah tangga berperilaku hidup bersih dan sehat. Jakarta, Pusat Promosi Kesehatan Depkes RI

Djatmiko, M., D. , Suhardjono, \& Nugroho, A. E. (2001). Uji praklinik efek farmakologi dan kisaran dosis jamu tensigard sebagai obat anti hipertensi. Majalah Farmasi Indonesia. 12(1), 38.

Genilda, M., Ratna, D. P., \& Yeni, S. (2013). Hubungan asupan natrium dan kalium dengan tekanan darah pada pasien hipertensi di unit rawat jalan di rumah sakit guido valadares Dili Timor Leste. Medika Respati. 8(1), 3.

Gusmira, S. (2012). Evaluasi penggunaan anti hipertensi konvensional dan kombinasi konvensional bahan alam pada pasien 
hipertensi di puskesmas wilayah Depok. Makara Kesehatan. 16(3), 77.

Inawati, Syamsudin, \& Winarno, H. (2006). Pengaruh ekstrak daun inai (Lawsonia Inermis Lilih) terhadap penurunan kadar glukosa, kolesterol total dan trigliserida darah mencit yang diinduksi aloksan. Jurnal Kimia Indonesia. 1(2), 71.

Julianti, E. D., Nunung, N., \& Uken, S. S. S. (2005). Bebas hipertensi dengan terapi jus. Jakarta: Puspa Swara.

Kristian, A. (2013). Uji teratogenik ekstrak etanol daun alpokat (persea Americana Mill) pada mencit betina (mus musculus). Jurnal Ilmiah Mahasiswa Universitas Surabaya. 2(1), 2.

Lindhlom, L. H. (2003). The problem of uncontrolled hypertension. Journal of Human Hypertension. 16(2), 3.

Mustikasari, K., \& Ariyani, D. (2008). Studi potensi binjai (mangifera caesia) dan kasturi (mangiferacasturi) sebagai antidiabetes melalui skrining fitokimia. Sains Dan Terapan Kimia. 2(2), 64.

Samawiyah, H. M. (2014). Uji efektivitas ekstrak daun kelor (Moringa Oleifera L) dalam menurunkan hipertensi pada hewan uji mencit. (Skripsi), FKIP UNTAD PALU, tidak diterbitkan.

Sangi, M. S., Momuatz, I. I., \& Kumaunang, M. (2012). Uji toksisitas dan skrining fitokimia tepung gabah pelepak aren (Arenga Pinnata). Jurnal Ilmiah Sains. 12(2), 127.

Septian, B. A., \& Widianingsih, T. D. (2014). Peranan Minuman Cincau Hitam Terhadap Penurunan Tekanan Darah. Jurnal Pangan Dan Agroindustri. 2(3), 198.

Smeltzer, S. C., Bare, B., Hilkle, J. L., \& Cheever, K. H. (2001). Brunner \& Suddarth Keperawatan medikal bedah, Edisi 8. Jakarta: EGC.

Soedarso. (2012). Srikaya. Surabaya: Stomata.

Solanki, P. (2011). Nilai gizi mentimun. Jakarta: Rineka.

Sudarni. (2000). Pembuatan jelly dari buah srikaya (Annona Aquamosa Linn). (Skripsi), FKIP UNTAD PALU, tidak diterbitkan.

Tarigan, H. G. (1990). Percikan budaya karo. Bandung: Yayasan Merga Silima. 